Artículo de investigación.

Cómo citar: Belisario, K., \& Meners, K. (2019). Critical analysis of the discourse on Judith Butler's visit to the cotry in the most popular online news portals. MEDIACIONES, 15(23), 91-106. https://doi.org/10.26620/uniminuto. mediaciones.15.23.2019.91-106.

Editorial: Corporación Universitaria Minuto de Dios - UNIMINUTO.

Recibido: 17 de septiembre de 2018

Aceptado: 25 de abril de 2019

Publicado: 12 de diciembre de 2019

Conflicto de intereses: los autores han declarado que no existen intereses en competencia.

ISSN: 1692-5688 | eISSN: 2590-8057

\section{Critical analysis of the discourse on Judith Butler's visit to the country in the most popular online news portals.}

\section{Análisis crítico del discurso sobre la visita de Judith Butler al país a través de los portales más populares.}

\section{Quem tem medo ao feminism no Brasil? Análise crítica do discurso da visita da Judith Butler ao país através dos portais mais populares.}

\begin{abstract}
In November 2017, feminist theorist Judith Butler travelled to Brazil to participate in an international conference. During the event, protesters gathered, carrying signs, chanting slogans, and burning an effigy of her while shouting, "Burn the witch!" According to media reports, these protesters wanted to preserve notions of the traditional nuclear family within Brazil and protect children against Butler's "diabolical gender ideology", which includes her theory that gender is a social construct and a cultural interpretation that overlaps with biological determinism. The protest attracted mainstream media attention. This article aims to identify the key discourses used by anti- and pro-Butler activists commenting in the most popular news portals in the country, UOL and G1. The questions guiding this study are:
\end{abstract}

1) How is feminism represented in Brazil? 2) How do protesters and counter-protesters understand and argue about "gender ideology"? The methodology used is the critical discourse analysis of online comments of readers of both portals.

Keywords: Gender, Feminism, Judith Butler, Discourse Analysis, Brazil. 


\section{Resumen}

En noviembre de 2017, la feminista Judith Butler viajó a Brasil para participar en una conferencia internacional. Durante el evento, manifestantes se reunieron, portando letreros, cantando y quemando una efigie de ella mientras gritaban “iquemen a la bruja!" Según los medios de comunicación, querían preservar la familia tradicional en Brasil y proteger a los niños de la "ideología diabólica de género" de Butler de que el género es una construcción social y una interpretación cultural que se solapan con el determinismo biológico. La protesta atrajo la atención de los medios. Este artículo tiene como objetivo identificar discursos anti y pro-Butler en los portales UOL y G1, los más populares del país. Las preguntas de búsqueda son: 1) ¿Cuáles son les argumentos de los manifestantes; 2) Cuál es su comprensión de la "ideología de género? La metodología utilizada es el análisis crítico del discurso de los comentarios de los lectores en los dos portales.

Palabras-Clave: Género, Feminismo, Judith Butler, Análisis del Discurso, Brasil.

\section{Resumo}

Em novembro de 2017, a feminista Judith Butler viajou ao Brasil para participar de uma conferência internacional. Duranteo evento, manifestantes se reuniram, carregando faixas, slogans e queimando uma efígie dela, gritando "Queimem a bruxa!" Segundo a mídia, eles queriam preserver a família tradicional no Brasil e proteger as crianças contra a "ideologia diabólica de gênero" de Butler, de que o gênero é uma construção social e uma interpretação cultural, que se sobrepõe ao determinismo biológico. O protesto atraiu a atenção da mídia. Este artigo objetiva identificar os principais discursos anti e pro-Butler nos portais UOL e G1, os mais populares do país. As perguntas são: 1) Quais são as argumentações dos manifestantes a favor e contra, e qual a compreensão da "ideologia do género"?; 2) A metodologia utilizada é a análise crítica do discurso dos comentários on-line dos leitores dos dois portais.

Palavras-Chave: Gênero, Feminismo, Judith Butler, Análise do Discurso, Brasil. 


\section{Introduction}

Miguel (2016) argues that reactions to gender equality cut across many fields and government policies; however, the main concern of conservatives is with education and, to a lesser extent, mass media.

According to Almeida and Cremona (2019), the launch of the book La ideologia de género o el género como herramienta de poder by the Argentinian pro-life lawyer Jorge Scala, in 2010, is a milestone in the implementation of the term "gender ideology" in South America. According to the authors, this term is aligned with dogmatic ideas of religious ultraconservatives, of which one major exponent is Joseph Ratzinger, a cardinal very close to Pope John Paul VI, who has been responsible for ensuring the orthodoxy of the Catholic faith from 1980 until the beginning of his own Pontificate (2005-2013, as Pope Benedict XVI), when he strongly instituted his own orientation within the church.

It was in this context that the philosopher and gender theorist Judith Butler came to Sao Paulo in 2017 to speak at a conference about the end of democracy. An online petition to cancel the conference gathered the signatures of over 370,000 Brazilian citizens even before Butler had arrived. During the conference, a group of protesters burned an effigy of Butler, saying she was a witch. This event generated significant mainstream media attention in Brazil and sparked a range of debates in the media, including in online news outlets. Even after the conference ended, protesters followed Butler and her partner to the airport, insisting that she was not welcome in Brazil and must return home with her "diabolical gender ideology". Butler explained: "the people who oppose me believe gender is a diabolical ideology" (Johnson, 2017), to which she countered that there is no single gender ideology, claiming that the question is more complex. She also emphasized that she had gone to the conference to discuss populism, authoritarianism, and concerns about the attack on democracy; no lecture about gender was planned.

This study conducts a critical discourse analysis of five news articles in the two most popular Brazilian portals, UOL and G1, as well as 154 comments on these articles. On the basis of this analysis, we argue that we can see the emergence in Brazil of conservative ideologies regarding family and gender. 


\section{The “Gender ideology” of Judith Butler}

Judith Butler is an American philosopher and gender theorist and a professor of Comparative Literature and Rhetoric at the University of Berkeley, California. Her theory on the social and performative nature of gender became very popular in the 1990s. These days her work is often misunderstood, and people with conservative and traditional values wrongly refer to her as the creator of "gender ideology" or a "diabolical gender ideology". Butler is one of the major modern theorists of feminism, politics, ethics, and queer theory. According to her, queer theory suggests that a person should not be identified only on the basis of gender. Instead, she argues, people have multiple elements to their personalities which form their identity. Thus, referring generally to a group is wrong, since it does not take adequate account of individual difference (Butler, 1990).

Butler argues that feminist theories limit themselves by accepting a concept of gender that reduces it to masculinity and femininity. She refuses to accept certain stereotyped notions of sexuality as norms and questions the belief that gendered behaviours are natural. In Butler's view, gender is culturally formed and performative: "We act and walk and speak and talk in ways that consolidate an impression of being a man or being a woman” (Butler, 2011).

So, in her view, "gender is the mechanism by which notions of masculine and feminine are produced and naturalized, but gender might very well be the apparatus by which such terms are deconstructed and denaturalized” (Butler, 2004, p. 43).

\section{Understanding the brazilian context}

In 2016, the first female elected president of Brazil, Dilma Rousseff, was impeached, accused of illegally moving funds betweengovernment budgets. Shedenied having done anything illegal, but the senate voted to suspend Rousseff and launch an impeachment trial against her. Rousseff accused her enemies of pre-empting the next presidential election by removing her. The politicians who backed Rousseff's impeachment are under investigation for corruption, and now all parties seem tainted by the allegations. Critics accused the president of trying to plug deficit-holes in social programmes to boost her chances of being re-elected in October 2014. Brazilians feminists used social media to express their solidarity with Rousseff during what they saw as a sexist and discriminatory impeachment. 
The unpopular and conservative vice-president Michel Temer became the acting president. His policies have reversed gains made in the areas of sustainability and minority rights. Under Temer, politicians voted against environmental achievements that had been on the books for decades and in favour of criminalizing abortions in cases of rape. They also excluded sexuality and gender issues from the Nation Education Plan. Feminists continue to denounce the attacks by Temer, currently president, on women's rights. In this context, the country has become divided into two main groups: 1) left-wing defenders of social movements, political activism, women's and minority rights, diversity, land reforms, sustainability, and socialism; and 2) right-wing conservatives, traditionally promoting big farmers, religious values, heterosexualism, military intervention, privatization, and neoliberalism.

The conservative, traditional group is now agitating for the preservation of Christian values, the traditional nuclear family, and the free market. The government, having already excluded gender and sexuality issues from the National Education Plan, also voices strong opposition to liberal social ideologies such as efforts at gender equality and women's reproductive rights. In September 2017, an art exhibition called "Queer Museum" that questioned sexuality and religion was cancelled after protests in the social media.

According to Almeida and Cremona (2019), a project that seeks to remove the gender problem in schools is consistent with the dramatic situation of violence and discrimination in Brazil. To Junqueira (2018),it is an initiative around which various social sectors can meet for different purposes, and particularly those with anti-political conceptions that are said to be non-ideological or anti-ideological.

In fact, a right-wing government has now risen to power in Brazil. The country recently elected (in October 2018) a far-right president named Jair Messias Bolsonaro who has expressed support for torturers and is "known for lashing out at women, minorities and indigenous groups" (The Guardian, 29 Oct, 2018). Bolsonaro's administration is "a return to a time of insecurity, with certainty about what a man is and what a woman is and a clear sense who is in charge of the public sphere and the family" (Brum, 2019).

Meanwhile, protests against so-called "gender ideology" are increasing, not only in Brazil, but elsewhere. The narratives are 
the same all across Latin America, with consequences for minorities, as Bessa points out:

As right-wing governments increasingly rise to power in Latin America and elsewhere, conservative movements feel legitimised and narratives like those creating the term "gender ideology" flourish, with serious consequences, especially for women and LGBTQ+ folks. As recently noted by the Open Society Foundations, although "gender ideology" is a fiction, the threat it poses is real. (Bessa, 2017).

\section{Methodology}

We chose five key articles about Judith Butler's visit to Brazil, published in the portals UOL and G1 between 07/11/2017 and $14 / 11 / 2017$. These are the most popular of the country. Portal UOL was founded in April 1996 and it is the largest content portal in Brazil. It was the sixth most-accessed portal in 2017 in Brazil, according to Alexa, an Amazon company. Portal G1 is maintained by Globo Broadcasting Group. It was founded in September 2006, and it was the fifth most-accessed portals in 2017, according to Alexa.

The articles studied are described at the reference. There you can see the headlines published by UOL and G1 during Butler's visit to Brazil.

\section{Critical Discourse Analysis}

"First, discourse should be defined as language in use. Second and consequently, newspaper discourse should be approached in such a way that assumes that it is an activity, or practice” (Richardson, 2007, p. 221). Richardson argues that critical discourse analysis (CDA) is concerned with social problems. It studies power in discourse and over discourse, the culture and the society, and also the history and context. As he points out, "Language may be ideological. To determine this is necessary to analyse texts to investigate their interpretation, reception and social effects” (Richardson, 2007, p. 28).

For Fairclough, the ideological work of texts naturalizes power relations, and it is most effective when its workings are least visible. Naturalization, according to this author, is the "royal road to common sense" (Fairclough, 1989, p. 92, cited by Deacon et al, 1999, p. 153). 
In this study, we focused on the ideological analysis of 154 comments by protesters and counter-protesters posted in the two portals. We found that after a certain period of time some of the comments were no longer available. We could not find comments on the articles "The passage of the philosopher Judith Butler at Congonhas airport ends at the police station" (UOL) and "Burn the Witch" (G1), but we kept the articles themselves in the study because the news pieces presented important details of the reaction to Butler's visit.

In total, we analysed 13 comments on "Protesters protest against and for American philosopher Judith Butler in Sao Paulo" and 91 on "Judith Butler: Protests were moved by ignorance". Portal G1 published $\mathbf{5 0}$ comments on "Groups protest in the West zone of Sao Paulo for and against philosopher Judith Butler". The arguments of protesters and counter-protesters are described in the following section.

\subsection{Protesters' Arguments}

The arguments of the protesters show the emergence of conservative ideologies regarding family and gender theory, a development which reflects the current Brazilian context after the impeachment of president Rousseff, the empowerment of rightwing forces such as MBL, ${ }^{1}$ and the emergence of conservative and traditional groups in the country. Much like Thatcherism in Britain in the 1980s, these groups articulate "the liberal discourse of 'free market' and economic man and organic conservative themes of 'tradition, family and nation respectability, patriarchalism and order”" (Hall,1988, p. 2).

Three main themes recur in the comments of protesters against Judith Butler's visit and what they call her "gender ideology".

1.Butler is a person who comes from hell to destroy Brazilian nuclear families and their Christian values.

2.She represents the witch and the Antichrist.

3.She opposes traditional biology.

1 With Margaret Thatcher and Rand Paul as inspiration, the MBL, or Free Brazil Movement, is among the leading groups that stand against president Dilma Rousseff. The movement defends liberalism and free market as a solution to the Brazilian problems. The movement also voices strong opposition to social liberal ideologies such as gender-equality efforts and women's' reproductive rights. Douglas, Bruce. Brazil Activists to walk 600 miles for 'free market, lower taxes and privatisations -' The Guardian, São Paulo.24/04/2015 
We translated the comments illustrating these themes from Portuguese to English.

\section{The "gender ideology" of the left destroys family values and beliefs and hurts children:}

"Gender ideology" is a term created to demerit Butler's gender and queer theory ${ }^{2}$. The right wing argues that her theory was propagated by leftists to destroy family values. The comments above show the rhetoric used by the right wing, which are said by Junqueira (2018) to be anti-ideological or non-ideological. For them, the leftists support promiscuity and teach sexuality to children; they also eroticize children.

Ok! To be against gender ideology is to be ignorant? To be against teaching sexuality to children is be ignorant? To defend our families is to be ignorant? So a person is only cool and smart when he supports promiscuity and things like that????? Eduardo SPZL, UOL, 14/11/2017

“Laughable left...kkkk” ddrey, UOL, 07/11/2017

"You have to stop giving importance and ignore these dumb Americans who have nothing to do and come here only to disturb us.” Adriana Oliveira, G1, 07/11/2017

"Leave our families in peace. \#OutJudith.” Jonathan Rufino, G1, 07/11/2017

"Why does no one see these manifestations of arts and ideology as a way of inducing sex to children in the poorest places like the slums of Rio de Janeiro?” John Benne, G1, 07/11/2017

"This rubbish that promotes the ideology of gender is not welcome. There's going to be a rally against yes. The only ones who support this nefarious ideology that aims to eroticize our children are disgusting lefties” Laura Rejane, G1, 07/11/2017.

\section{The philosopher as witch and Antichrist:}

Butler was depicted as a witch and as the Antichrist, and the protesters urged one another to "burn the witch" and put her to run as the inquisitors did in the Middle Ages. God and faith are emphasized as bastions of conservative values.

2 https://www.theguardian.com/world/2015/apr/24/brazil-activists-march-free-marketsmargaret-thatcher-rand-paul 
This woman is the Antichrist in person.” Randall Flag, UOL, 07/11/2017

"Good! Straighten out Brazil, put the witch to run.” maisdemenos, UOL, 07/11/2017

"It is no rumour, it is cultural! God transform you!” Rita Sabioni, UOL, 07/11/2017

“Conservative Sao Paulo puts the witch to run!” Maisdemenos, UOL, 07/11/2017

"She climbed on her broom and took off, hope she never comes back, bye!!!” Julia Minervia, UOL, 14/11/2017

These comments make an emotional appeal (pathos) in their rhetoric, attempting to manipulate the audience into believing Butler is a witch, an Antichrist, and a person who opposes God and traditional values. They argue that the philosopher came to Brazil to teach Brazilian families how to raise their children and to destroy Brazilian families. The language they use is charged with emotion, but no valid arguments or evidence are offered.

\section{“Gender ideology” goes against tradition and biology:}

The biological approach explains that chromosomes are the fundamental cause of gender differences (two X chromosomes yield a baby girl, whereas an X and a Y produce a baby boy). The biological differences between men and women result in differing behaviours. As already discussed, Butler refuses to accept the reduction of the concept of gender to masculinity and femininity; she also refuses to accept certain stereotyped notions of sexuality as norms. Protesters think she promotes homosexuality and LGBT lifestyles. They make the common-sense objection that Butler's theories have not been scientific proven (Fairclough, 1989) to argue against the philosopher and naturalize their own position.

"She is a reference in "gender' theory. Any biology book from middle school overturns her theory." Rodrigo Araújo, G1, 07/11/2017)

"Philosopher? Just a left-winger talking shit that talks about gender ideology, a theory that has no theoretical foundation." Fabio dos Santos Silva, G1, 07/11/2017

"A bitch responsible for propagating the disgusting rot of something that is not natural or scientific, just a slutty bitch funded by scoundrels. 
All she cares about is money." Marcel Augusto Martin, G1, 07/11/2017

"Hiding behind the cover of philosopher does not justify your inability to validate your ideology.” Visitante, UOL, 14/11/2017

The comments above show the charged emotions of the protesters, who are personally offended by Butler's visit and clearly appeal to the audience, manipulating them. They use obscene language and insults, calling Butler "bitch" or taunting, "Hiding behind the cover of philosopher does not justify your inability”.

\subsection{The Arguments of the Counter-Protesters}

The main themes of these comments are the ignorance, misinformation, and prejudice of the protesters. They question the ideas of "morals and good manners", which are the stated values and beliefs of the protesters. They also assert that the public should be more worried about the problems of the country (corruption and economic crisis) than about how people raise their children or live their lives. Three ideas recur in these comments.

\section{Protesters are ignorant and uneducated}

The left-wing and more progressive discourse emphasizes the ignorance of the protesters and the fact that they are not well informed about Butler's theory and ideas. They think the protesters are ignorant and uneducated and that they expose the country to shame.

"Brazilians are doing what they do best: exposing themselves to shame.” Glauber CL, UOL,14/11/2017

"Poor people of Brazil. People who judge shallow and superficially. They are filled with conviction based on ignorance and they embarrass themselves and the rest of the nation. Brazil lives unhappy days.” Evidente QN, UOL,14/11/2017

"Have you ever read her work? Better to inform yourself." Litur, UOL, 07/11/2017

"People are not interested in philosophy and suddenly we have a movement against a philosopher... People don't know what she writes about... they read a title of a story and they go on 
and on about it. They burn the witch then. A lot of ignorance. A lot of Middle Ages.” Cassia Maria Amanajas Bezerra, G1, 07/11/2017 "Galileo was almost burned for saying that the earth was round, he had to go back and apologize for not dying. Is this the time we're going back to?” 4U2, UOL, 14/11/2017

As we can see, the counter-protesters also use emotional appeals and insult the protesters regarding their ignorance. Education is a main concern of conservatives, but here it is used in the arguments of the counter-protesters.

\section{The importance of freedom of expression, feminism, and equality}

The idea that the people have the right to express their ideas about feminism, women's equal rights, and the fact that "freedom of expression" is part of democracy appear in the discourse of the counter-protesters. Freedom of expression and speech are protected in the Brazilian Constitution and are rights of every Brazilian citizen. Everybody has the right to voice his or her own opinion.

"A protest like this is against freedom of expression, why are these people so angry with feminism? Ignorance or lack of character? Don't they like equality? For sure they do not even know what she talks about in her work and accuse her based on internet idiocy and gossip, in anger from the left...Unfortunate.” Guilherme, UOL, 07/11/2017

"The image says a lot about protesters. Representing the philosopher as a witch, they take the place of inquisitors bringing the society to the Middle Ages. The supposed 'freedom of speech' is a mere rhetorical instrument. They cannot stand difference, and it would be more honest to assume this position." Marcos, UOL, 07/11/2017

"I just think you can give your opinion without verbally assaulting anyone, much less act in such a way (burning the witch, are we in the middle ages?). The world has already so much hate, why multiply this hate?” Rafaella Rodrigues, G1, 07/11/2017

"Sick people, imagine someone protesting against a philosopher? This is a great expression of fascism: gag, stifle, eliminate the other, what a sick society! Brazil takes reverse steps from the Age of Enlightenment into the darkness of the Middle Ages.” Pedro Lira, 07/11/2017 
"You can notice that all defenders of 'moral and good manners' aim to make society regress economically and socially to the past.” LUIZ?0, UOL 07/11/2017

“This fundamentalist 'wave' makes me tired! Now, everything that involves sex, gender, and sexuality has become sin, taboo, or whatever they want. Have these people ripped their genitals off, or do they just make love by wi-fi? Hypocrites." Jane Soares Cruz Cabral, G107/11/2017

"We live in a democracy, and in a democracy we respect the opinion of the majority. They may shout and make noise on the internet, but the Brazilian people have strong character and have great love in their heart. Love for our family in the first place.” Mister Carlos, UOL, 14/11/2017

"What could you expect from people who support $\mathrm{MBL}^{3}$ and Alexandre Frota?" ${ }^{4}$ Radynne Loureiro, UOL,14/11/2017

"The debate over different ideas is beautiful and enriching, as long as it does not oppose to the thought of ones. And long live democracy in the country!!!” Maubruno, UOL, 14/11/2017

The media creates a common sense of the world through its language and symbols, providing an ideological support for hegemonic power structures (Meyers,1994, p. 47-63). These comments shows how the media plays a key role in the maintenance of the dominant culture: "Subordinated groups - women, people of color, the poor and working class, lesbians and gay men, the elderly - are encouraged to 'buy into' the dominant ideology which, in fact, maintains the status quo by keeping them subordinated" (Meyers, 1999, p. 7).

\section{There are more important things to think about in the country}

The counter-protesters also argue that there are more important things to worry about in Brazil than Judith Butler's visit. They mention such things as corruption, pension reforms, social policies, taxes, and so on. They think that the forms of

3 .The MBL defends liberalism and the free market as a solution to Brazilian problems. It opposes liberal social ideologies such as gender-equality efforts and women's reproductive rights.

4 Alexandre Frota is a former pornographic movie actor who became a Brazilian politician and who now represents the conservative government. 
intimacy adopted by others and their sexual orientation is no one else's business, nor the way people raise their own children. They criticize the right and what they perceive as a conservative misunderstanding of Brazilian problems.

"Go to work, bunch of bums! People who do not have enough to do and usually criticizing the government." UOL, 07/11/2017

"The country sunk in corruption and people worried how parents are going to raise their children? If you're not doing anything illegal, it is ok. Everyone should mind his own business. You should not allow a country standing up to your kids and should not worry how your neighbour is raising his kids or who he is sleeping with. Brazil is becoming a land of gossip and spies of other lives.” Ju22, UOL, 07/11/2017

"The conservative agenda is great, right? They protest against corruption? Taxes? Pension reform? Slave labor? No, they only call to protest against the museum and the philosopher. It gives us the impression that the articulators have no interest in the welfare of the majority of the population and they only want to divert attention to minor things by creating spectacles and disseminating misinformation, which is curious." Felipe Kouwen, G1, 07/11/2017

-"This is what happens: 14 million unemployed people in Brazil without having to do what they will do with everything that happens in the country. I hope you get better kkkk.” Emmanoel Rabelo, G1, 07/11/2017

"People do not protest against corruption, which is necessary. While these idiots are making a pointless protest, the government continues to steal from the people. Only in Brazil!” - Luiz Baratheont, G1,07/11/2017

“Continue protesting against such a 'gender ideology', meanwhile the Brasilia gang takes advantage. Strange those people who forgot to protest against corruption. It seems that they want to elect playboys to became as the last government of PT.” Jacar?, UOL, 11/07/2017

\section{Conclusion}

The gender theorist Judith Butler came to Brazil to discuss democracy in a difficult moment for the country and its people. The unpopular and conservative Michel Temer had just became president in 2016 after left-wing Dilma Rousseff's impeachment. His policies took the country backwards in terms of minority rights. The conservative groups known collectively as the Brazilian Free Movement (MBL) were advocating the "free market" and making 
strong opposition to liberal social ideologies such as efforts at gender equality and women's reproductive rights.

In this context, Butler's gender theory was highly unwelcome to the extremely conservative and traditional groups in power. They protested against her and even burned her picture as a witch and Antichrist. In their view, Butler creates what they call a "gender ideology" of the left that aims to destroy their families and their Christian values. Feeling that she wants to teach them how to raise their own children, they used obscene language, insults, and emotional appeals to the audience.

On the other hand, according to the counter-protesters, these conservative groups are ignorant and uneducated and misunderstand Butler's theory. Counter-protesters argued that the protesters were behaving like inquisitors from the Middle Age and shaming the country. In their view, there are more important things to worry about in Brazil, such as corruption, reforms, and social policies. Like the protesters, they also used emotional appeals.

Here we present comments from both sides (the traditional and conservative right wing and the liberal left wing) published in UOL and G1 portals. Based upon Richardson and Fairclough's critical discourse analysis, we analyse both sides of the arguments, giving due consideration to the Brazilian context and culture and the history of our people.

We conclude that Brazilians are not yet fully prepared for Butler's ideas and concepts. The conservative groups in power at the moment are in fact afraid of the contemporary feminism that Butler represents, particularly after far-right Bolsonaro won the presidential election in 2018. His non-ideological or anti-ideological discourse emphasizes that "gender ideology" and leftist ideas represent a danger to the country and to the good citizens of Brazil. For him, "God above everything, Brazil above all."

\section{References}

Almeida T., y Cremona, F. (2019). “Ideologia de Gênero”, Comunicação e Educação no Brasil e na Argentina. IN: 
Belisário, Katia et all. Gênero em Pauta: Desconstruindo Violências, Construindo Novos Caminhos.Curitiba: Editora Appris.

Azevedo, D. Queime a Bruxa. G1, Quarta-feira, 08/11/2017.

BBC Latin America. (2016). Brazil Impeachment: Key Questions. 31 August 2016.

Bessa, T. (2017). Judith Butler, "gender ideology" and the rise of conservatism in Brazil. Feminist Academic Collective.

Brum, E. (January 10, 2019). He's been president a week - and already Bolsonaro is damaging Brazil. The Guardian.

Buarque, D. (November 14, 2017). Judith Butler: Protestos contra palestra foram 'movidos pela ignorância'. Blog do Brasilianismo. Uol Notícias

Butler, J. (1990). Gender Trouble: Feminism and Subversion of Identity. New York: Routledge, Chapman \& Hall, Inc.

Butler, J. (2004). Undoing Gender. New York: Routledge

Butler, J. (2017). Judith Butler escreve sobre sua teoria de gênero e o ataque sofrido no Brasil.

Deacon, D., Pickering, M., Golding, P., \& Graham, M. (1999). Researching Communications: A Practical Guide to Methods in Media and Cultural Analysis London: Holder, Arnold.

Garcia, J. (November 11, 2017). Manifestantes protestam contra e a favor de filosofa americana em Sao Paulo. UOL Sao Paulo.

G1 Portal. (November 12, 2017). Grupos protestam na Zona Oeste de Sao Paulo a favor e contra a filosofa Judith Butler. Globo

Hall, S. (1988). A Hard Road to Renewal: Thatcherism and the Crisis of the Left. London: Verso. Google Scholar.

Hao, A. (July 05, 2016). In Brazil women are fighting against the sexist impeachment of Dilma Rousseff. The Guardian.

Johnson, C. (November 8, 2017). About 70 protest UC Berkeley professor Judith Butler's conference in Brazil. The Daily Californian, Berkeley News, Wednesday.

Jornal o Globo. (November 11, 2017). Polêmicas cercam segunda vinda de Judith Butler ao Brasil. O Globo. 
Junqueira, R.D. Entrevista. A Gênese de uma categoria. http// www.clam.org.br/destaque/conteudo.asp?cod=

Mendonça, H. (September 13, 2017). Queermuseu: o dia em que a intolerância pegou uma exposição para cristo. São Paulo: Brasil. El País.

Meyers, M. (1999). Mediated Women: Representations in Popular Culture. New Jersey: Hampton Press.

Miguel, L. F. (2016). Da "Doutrinação Marxista” à “Ideologia de Gênero": Escola Sem Partido e as leis de mordaça no parlamento brasileiro. Rio de Janeiro: Direito \& Praxis, V.07, n15, p. 590-621.

Richardson, J. E. (2007). Analysing Newspaper: An Approach from Critical Discourse Analysis. New York: Palgrave Macmilliam

The Guardian. (2018). Who is Bolsonaro? Brazil's far-right President in his own words.

Vice Brasil. (Novembro 10, 2017). Judith Butler foi perseguida no aeroporto de Congonhas.

\section{Portals Analysed}

Garcia, J. (November 7, 2017). Manifestantes Protestam contra e a favor de filósofa Americana Judith Butler em São

Paulo. Portal Uol, Cotidiano, Grupos protestam na Zona Oeste de Sao Paulo a favor e contra a filosofa Judith Butler.). São Paulo. (November 7, 2017). Portal G1.

Passagem da filósofa Judith Butler por Congonhas termina na Delegacia. (November 10, 2017). Portal Uol.

Azevedo, D. (Novembre 8, 2017). Queime a Bruxa. Portal G1, Dodô Azevedo,.

Buarque, D. (November 11, 2017). Judith Butler: Protestos contra palestra foram 'movidos pela ignorância'. Portal Uol, Blog do Brasilianismo. 